\title{
An Analysis of the Expected Effect of Levying Inheritance Tax on Capital Outflows
}

\author{
Chengfei Qiu \\ College of Economics, Jinan University, Guangzhou, China \\ Email: chengfeiqiu@foxmail.com
}

How to cite this paper: Qiu, C.F. (2018) An Analysis of the Expected Effect of Levying Inheritance Tax on Capital Outflows. Technology and Investment, 9, 24-35. https://doi.org/10.4236/ti.2018.91002

Received: January 8, 2018

Accepted: February 4, 2018

Published: February 7, 2018

Copyright $\odot 2018$ by author and Scientific Research Publishing Inc. This work is licensed under the Creative Commons Attribution International License (CC BY 4.0).

http://creativecommons.org/licenses/by/4.0/

\section{c) (i) Open Access}

\begin{abstract}
With the constant development of reform and opening up, China's economy and society obtain considerable development; the living standards of the people continuously improve, and the economic inequality in China widens day by day. Therefore, the voice for demand of levying inheritance tax to regulate the economic inequality becomes louder and louder, but the substitution effect of taxation makes us consider the negative impact of inheritance tax on economic efficiency. This text selects the effect of levying inheritance tax for the capital outflows as the breakthrough point, and makes empirical analysis on its expected effect for capital outflows. The conclusion indicates that the levy of inheritance tax will accelerate our country's capital outflows. Facing the economic and social situation in our country, this text considers that China is not suitable for levying the inheritance tax at current stage and we need to take other measures to adjust the economic inequality.
\end{abstract}

\section{Keywords}

Inheritance Tax, Substitution Effect, Economic Inequality, Capital Outflows

\section{Introduction}

Chinese People's Livelihood Development Report [1] [2] released by Peking University points out that the Gini coefficient of resident property in our country reached 0.73 in 2012 and Li Shi (2015) [3] believes that Gini coefficient of Chinese property reached 0.739 in 2010, which shows that the Gini coefficient of Chinese property has the trend of expanding.

The report of the $19^{\text {th }}$ National Congress of the Communist Party of China put forward "perform governmental functions of redistribution and adjustment, accelerate the equal basic public services, and narrow the gap in income distribution", which is not only the need to adjust the economic inequality, but also the 
inevitable requirement of socialist modernization.

In terms of another aspect, with the constant improvement of the level of open economy in our country and gradual opening of the capital account in China, the situation of our country's international balance of payments is increasingly serious, and the scale of capital outflows also gradually expands.

If our country levies the inheritance tax at current stage, will our country's capital outflows scale further expand? This text takes the expected effect of levying inheritance tax for the capital outflows in China as the breakthrough point to discuss this problem from the qualitative and quantitative perspectives, and discuss if China is suitable for levying inheritance tax in the current stage based on this.

\section{Literature Review}

Foreign scholars started to study on inheritance tax early; they have conducted research in the fields of the fair effect of levying inheritance tax, the intergenerational wealth transfer, the impact on investment, the choice of consumption and savings, etc. Regarding to the research on the relationship between inheritance tax and capital outflow, they studied in-depth on capital flows from the perspective of capital taxation.

Studies conducted by China's local scholars on inheritance tax mainly focus on learning the experiences from foreign countries regarding to levying inheritance tax, the research on the design and legislation of China's tax system, and whether China should levy inheritance tax, etc. Some scholars have made some discussions in the aspect of the relationship between levying inheritance tax and capital outflow, and formed different viewpoints.

Some scholars believe that levying inheritance tax would not cause capital outflow. From the perspective of economic globalization, Han Lin (2002) [4] concluded that levying inheritance tax in China could effectively prevent the riches transferring their properties to foreign countries by means of legal gift. In the meantime, levying inheritance tax could also form a kind of psychological expectation that the laws could protect private properties, and to some extent, it could also reduce the motivations of the riches for transferring their properties abroad. Liu Zuo (2003) [5] believed that transferring property in our country would be subject to various restrictions, and transferring assets to foreign countries would either face more stringent management, or the investment environment in China was better than relevant countries, and then concluded that China had ripe conditions for collecting inheritance tax. Moreover, Liu Rong et al. (2013) [6] held that the abolition of inheritance tax in Hong Kong was aimed at attracting foreign investment to strengthen its status as the International Financial Centre, and this practice in Hong Kong had no referential significance for the mainland. At the same time, the levying practices in many countries showed that as long as the tax system could be reasonably designed, the inheritance tax would not be the reason for the abnormal change of capital outflow. Shan 
Shun'an (2013) [7] pointed out that levying inheritance tax for fairness would promote the efficiency and would not have greater impacts on capital outflow.Jia Kang (2014) [8] argued that if we only considered tax burden, the riches would have to flee to developed counties with higher tax burden or tax havens with small markets. The real way to retain capital should be to develop economy energetically and improve relevant systems to give the security of capital. Gao Fengqin, et al. (2015) [9] believed that there was no obvious phenomenon of capital outflow according to the practices of collecting inheritance tax in OECD countries.

Some other scholars believe that levying inheritance tax would have impacts on capital outflow, they would not stand for levying such tax. Peng Fei et al. (2003) [10] pointed out that if China would collect inheritance tax, the riches would transfer their properties, which would cause more serious capital flight in our country. Based on the figures of the number of Chinese students studying abroad in recent years, Xie Baisan et al. (2014) [11] believed that if China would start to levy inheritance tax, the trend of the riches transferring properties to their next generations abroad would become more and more obvious. Li Hua et al. (2015) [12], relying on the background of economic globalization, put forward that in order to attract foreign capital to develop our economy, it should not levy inheritance tax at this stage.

Furthermore, many scholars tend to analyze the impacts of inheritance tax on capital outflow proceeding from the realistic situations. Liu Rong et al. (2013) [13] pointed out that appropriate capital outflow would not have great impacts on China's economy, and the inheritance tax was not only levied in China, but the most important thing was to reasonably determine the tax burden level of inheritance tax. Huang Chaoxiao (2013) [14] believed that levying inheritance tax would significantly influence the riches in China, therefore, the middle class should not be included in the scope of inheritance tax, and the tax rate should be designed to be equivalent to the costs of transferring capital overseas, preventing capital outflow through these two methods. Moreover, Gao Fengqin et al. (2013) [15] concluded that people could transfer properties in order to avoid tax, but the capital outflow in China at present was not related to tax factors, more because of education, medical treatment and other reasons. Xie Baisan et al. (2013) [16] said that capital flow should not be considered only from the perspective of taxation, the more urgent task for our country should be to develop the economy, and it did not have ripe conditions for levying inheritance tax at this stage.

On the basis of above-mentioned research on the relationship between inheritance tax and capital outflow, most of the scholars' conducted descriptive analysis on the relationship between the two from a qualitative perspective, and there was no quantitative description. In the face of the widening gap between the rich and the poor, and the increasingly severe balance of payments situation in China, it is particularly important to analyze the relationship between them quantitatively. Therefore, this paper will study the expected effect of levying inherit- 
ance tax on capital outflow from a quantitative point of view, and conduct further discussion according to this.

\section{Empirical Analysis of the Expected Effect of Levying Inheritance Tax on Capital Outflows}

This text takes the theory of international capital flow theoretical basis, combines with the multi-factor model, selects the relevant economic data in China, and establishes VECM model to analyze the expected effect of levying inheritance tax in China for the capital outflows.

Table 1 shows the selected economic variables and the sources. We will use these variables to make empirical analysis.

\subsection{Stationary Test}

The text takes ADF test method to examine the stability of variable, The results are as follows:

Table 2 shows that $\mathrm{Y}, \mathrm{X} 1, \mathrm{LNX} 2, \mathrm{LNX} 3$ and X4 are not stable. However, Y, $\mathrm{X} 1, \mathrm{LNX} 2, \mathrm{LNX} 3$, and $\mathrm{X} 4$ are uniformed and integrated, so they own the basis for implementing co-integration test, if there is a co-integration relationship between these variables, we can set up a VECM model to analyze the impact of macro tax burden on capital outflows, and then further analyze the expected effect of levying inheritance tax in China for capital outflows.

\subsection{Co-Integration Test}

This text takes the Johansen co-integration test to examine the co-integration relationship, laying the foundation for the next empirical analysis.

These five variables $\mathrm{Y}, \mathrm{X} 1, \mathrm{LNX} 2, \mathrm{LNX} 3, \mathrm{X} 4$ are selected to establish VAR model.

Table 1. The selected economic variables and data sources.

\begin{tabular}{ccc}
\hline Economic variables & Variables & Data sources \\
\hline Capital outflows & $\mathrm{Y}$ & $\begin{array}{c}\text { The website of State Administration of } \\
\text { Foreign Exchange }\end{array}$ \\
The difference of real interest rate & $\mathrm{X} 1$ & Wind database \\
Exchange rate & LNX2 & Wind database \\
House price index & LNX3 & State Statistics Bureau \\
Macro tax burden & $\mathrm{X} 4$ & State Administration of Taxation
\end{tabular}

Table 2. Stationarity test results of variables.

\begin{tabular}{cccccc}
\hline Variables & Y & X1 & LNX2 & LNX3 & X4 \\
\hline Stationary & Unsteady & Unsteady & Unsteady & Unsteady & Unsteady \\
Variables & DY & DX1 & DLNX2 & DLNX3 & DX4 \\
Stationary & Steady & Steady & Steady & Steady & Steady \\
\hline
\end{tabular}


Figure 1 shows that the VAR model is steady. According to AIC criterion and $\mathrm{SC}$ rule, the lagged differences of VAR model is order 1, thus, the lagged differences of Johansen co-integration test is order 0.

Table 3 shows that there is one co-integration relationship between these five variables, and the results of the maximum statistical test show that there are two co-integration relationships between the five variables. In this case, we choose the test results of the trace statistics; namely, there is 1 co-integration relationship between Y, X1, LNX2, LNX3 and X4.

\section{Inverse Roots of AR Characteristic Polynomial}

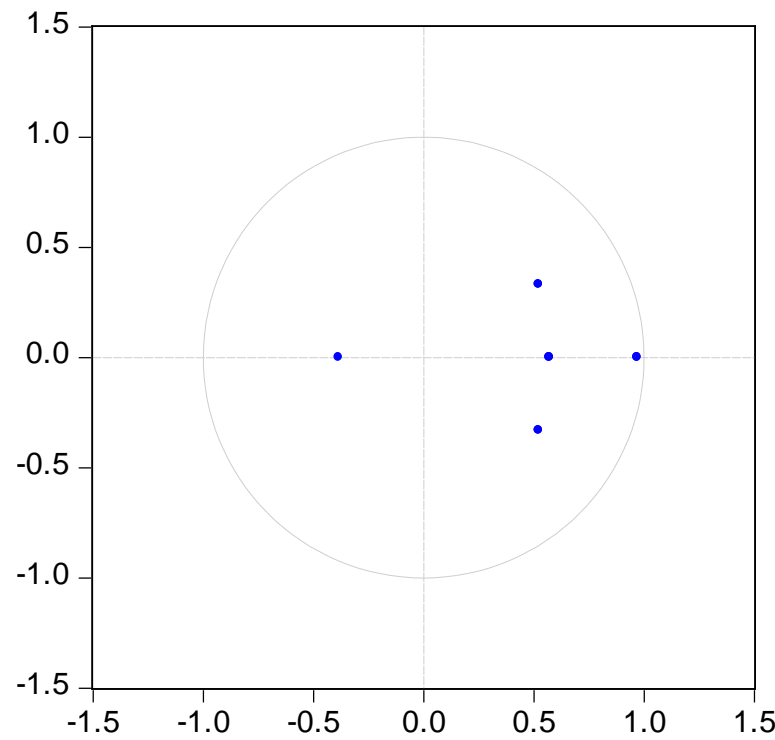

Figure 1. The AR root of the VAR model.

Table 3. Johansen co-integration test results.

\begin{tabular}{|c|c|c|c|c|}
\hline \multicolumn{5}{|c|}{ Unrestricted Cointegration Rank Test (Trace) } \\
\hline Hypothesized No. of CE(s) & Eigenvalue & Trace Statistic & 0.05 Critical Value & Prob.** \\
\hline None $^{*}$ & 0.89535 & 84.11502 & 69.81889 & 0.00240 \\
\hline At most 1 & 0.80973 & 45.74376 & 47.85613 & 0.07790 \\
\hline At most 2 & 0.48898 & 17.53531 & 29.79707 & 0.60050 \\
\hline At most 3 & 0.29364 & 6.12254 & 15.49471 & 0.68100 \\
\hline At most 4 & 0.01245 & 0.21293 & 3.84147 & 0.64450 \\
\hline \multicolumn{5}{|c|}{ Unrestricted Cointegration Rank Test (Maximum Eigenvalue) } \\
\hline Hypothesized No. of $\mathrm{CE}(\mathrm{s})$ & Eigenvalue & Max-Eigen Statistic & 0.05 Critical Value & Prob.** \\
\hline None $^{*}$ & 0.89535 & 38.37125 & 33.87687 & 0.01360 \\
\hline At most $1^{\star}$ & 0.80973 & 28.20845 & 27.58434 & 0.04160 \\
\hline At most 2 & 0.48898 & 11.41278 & 21.13162 & 0.60610 \\
\hline At most 3 & 0.29364 & 5.90961 & 14.26460 & 0.62480 \\
\hline At most 4 & 0.01245 & 0.21293 & 3.84147 & 0.64450 \\
\hline
\end{tabular}




\subsection{Establish the Vector Error Correct Model}

There is one co-integration relationship between variables Y, X1, LNX2, LNX3 and $\mathrm{X} 4$, so we can establish VECsM model to analyze the expected effect of levying inheritance tax in China for capital outflows, and the results of the VECM model are as follows:

$$
\begin{aligned}
\text { CointEq1 }= & \mathrm{Y}-2642.3 \mathrm{X} 1-608682.3 \mathrm{LNX} 2-727080.6 \mathrm{LNX} 3 \\
& -1329653 \mathrm{X} 4+3080515
\end{aligned}
$$

This long-term co-integration equation can also be written in following form:

$$
\mathrm{Y}=\text { 2642.3X1+608682.3LNX2 + 727080.6LNX3 + 1329653X4 - } 3080515
$$

According to this long-term co-integration equation, we can see that if the other conditions are unchanged and the macro tax burden increases by 1 , the capital outflows will increase by $13,296,530$ billion dollars.

Provided that other conditions are invariant, if the inheritance tax is levied, in accordance with the computing method provided by relevant documents (namely, the tax revenue of inheritance tax accounts for roughly $0.4 \%$ of total tax revenue in a country), the macro tax burden will change to $1.004 \mathrm{X} 4$ from $\mathrm{X} 4$, and capital outflows will increase by $13,296,530^{*} 0.004=531.861$ billion dollars.

Faced with a serious situation for international balance of payment in our country, if 531.861 billion dollars of capital outflows is increased on the current basis, China's international balance of payment will get huge impact, which is not conducive to the stability of China's international balance of payments and it is bed for the development of domestic economy.

This chapter takes the theory of international capital flow as theoretical basis, selects China's scale of capital outflows, the difference of the real interest rate, the dollar/RMB NDF (12 months), house price index, macro tax burden as variables, and sets up VECM model on the basis of stability test and co-integration test to analyze the impact of macro tax burden on the scale of capital outflows. On this basis, the text discuss the expected effect of levying inheritance tax in China for capital outflows by using the conclusions obtained from relevant document researches. It thinks that the levy of inheritance tax will accelerate the excepted effect for capital outflows. In the face of the accelerated anticipated effect of levying inheritance tax for capital outflows, we need to study the levy of inheritance tax prudently.

\section{China Is Not Suitable for Levying Inheritance Tax in Current Stage}

\subsection{The Scale of Capital Outflows Sharply Increases}

The scale of capital outflows in China was in a relatively stable level from 1999 to 2013, and there was no large-scale inflow or outflows. However, the capital outflows sharply increased in 2014; in 2015, it continued to increase to maximum value on the basis of 2014; in 2016, although it fell after rise, but compared with 1999-2013, it is also at a high level. 
The expansion of capital outflows scale is the result of the development of open economy; on the other hand, there are some unreasonable capital outflows, which are not conducive to the long-term development of China's economy.

In the face of the present situation of the capital in our country, if the inheritance tax is levied at current stage, it will bring huge impact to China's international balance of payments, which is not conducive to the stability of China's international balance of payments and will bring many adverse effects for economic and social development.

\subsection{The Economic Development Level Is Lower}

Economic foundation is the basis of policy implementation, and the low level of economic development in our country at present stage is a practical problem we face. Compared with other developed countries in the world, the developmental level of our country lags far behind. Based on this background, we still need to be based on this biggest reality, taking economic construction as the central task to give play to the initiative of all elements. If the inheritance tax is levied at the present stage, it will encourage some capital outflows that should serve for the economic development, which is bad for the long-term development of China's economy.

\subsection{The Development of Substantial Economy Needs More Capital Input}

With the rise of the virtual economy, more money in society is invested to the virtual economy. Compared with the boom of virtual economy, the development of real economy is at the low ebb. In 2016, the growth rate of private fixed-asset investment was less than $1 / 3$ of 2015 , which is the slowest pace since the data statistics were recorded.

At the same time, China's capital is circulating in the real estate and financial system. From the data of social financing scale, in 2016, social financing scale increment in China is RMB 17.8 trillion, but the new debt of industrial enterprises above designated size is only about RMB 4 trillion; in brief, the loans obtained by large industrial enterprises is less than a quarter of total social financing scale. Most funds enter into two fields: the real estate and finance; on the one hand, the higher lever will be accumulated in the real estate and financial industries, bringing some risks, and cost of investment and operating cost of entity enterprises will be increased to hinder the process of economic transformation and upgrading.

If the inheritance tax is levied at current stage, the capital that should have entered into substantial economy for expanding reproduction is allocated to other channels, such as, to allocate it to the regions in other countries with low tax rates, etc., which is extremely bad for the development of the real economy.

\subsection{The Establishment of Tax Collection and Administration System in China Lags Behind}

In terms of the tax collection and administration system in our country, China 
does not have the conditions to levy inheritance tax. In this case, the levy of inheritance tax will be conducive to the high income group to carry on the tax planning, and increase the scale of capital outflows in China.

Firstly, there is a lack of evaluation system for resident property in China. In addition to monetary assets, heritage also has a lot of physical assets and intangible assets that can be measured by money, and one of the important foundations of levying inheritance tax is the need to fully evaluate the property. At present, China lacks the corresponding system in the appraisal of resident property, and there are few subjects in the market to participate in the appraisal of resident property.

Secondly, there is no unified registration system for resident property in China. Heritage has many types, including monetary funds, securities, immovable property-real estate, and movable property-cars, etc. We should make uniform dynamic registration and management for resident property. If the system can't be set up, it is bad for management of taxation of inheritance tax; on the other hand, it also reduces the function of inheritance tax for adjusting the economic inequality.

In the absence of the conditions of collection and management, the levy of inheritance tax will create certain condition for capital outflows, leading to the expansion of capital outflows in China.

To sum up, from the economic and social situation faced by China, our country does not have the condition for levying inheritance tax, so it is not suitable for levying the inheritance tax at the current stage.

\section{Actively Take Measures to Adjust the Economic Inequality in China}

After the analysis of the above text, China does not have the condition to levy inheritance tax, which is not suitable for levying inheritance tax at current stage. However, the economic inequality in China continuously extends, so, we need to start from the following aspects to make necessary adjustments to the economic inequality:

\subsection{Handle the Relation between Fairness and Efficiency Correctly}

Theory of dialectical relationship between fairness and efficiency is the important guiding ideology to regulate the economic inequality; how to understand and deal with the relationship between fairness and efficiency is related to the stable and long-term development of economy and society.

Theory of dialectical relationship between fairness and efficiency suggests that the relationship should be treated by a dialectical perspective, that is, the efficiency is the material basis of fairness and the fairness is the guarantee of efficiency, so the relationship between them is dialectical.

In the face of the increasing expansion of economic inequality in our country, we must use the dialectical view to deal with the problem of fairness and effi- 
ciency; if this problem can't be dealt with, many unstable factors will be brought to China's social development, which is not conducive to the long-term development of society and economy. Therefore, we need to take account of efficiency and fairness, and actively promote reforms to safeguard social fairness without damaging the economic efficiency.

\subsection{Reform the Current Tax System in China}

At present, the tax levied on the personal property in our country mainly includes personal income tax, property tax and consumption tax which is levied to adjust high consumption. These tax categories have the function of regulating the economic inequality to some extent, but they fail to achieve the desired effect of tax system design in the process of implementation.

First of all, the complex tax system design of China's individual income tax has brought about a certain adverse regulation effect on the adjustment of the economic inequality. In addition, the tax collection and management level of individual income tax in our country needs to be improved, so that individual income tax cannot really adjust the economic inequality at this stage.

Secondly, China is lack of property tax that can adjust the economic inequality in a real sense. From the structure of tax system in our country, our country has many types of property tax, including the land value increment tax, building tax, city and town land use tax, deed tax, and vehicle and vessel tax, but these tax categories can't play important role in adjusting the economic inequality.

Last but not the least, the items of consumption tax that China sets for some products with high consumption have little regulating effect on the economic inequality. China's consumption tax is only partially levied at the retail links, which provides certain amount of tax avoidance space for many expensive consumer goods.

When there is no condition in China for levying inheritance tax, we need to reform the existing tax system in our country: advance the reform combined with classification and comprehensive collection of individual income tax, complete the existing property tax, and properly adjust the link of levying consumption tax for high consumption, etc. If the reform of the existing tax system is properly promoted, it will also play an important role in adjusting the economic inequality.

\subsection{Encourage the Development of Philanthropy}

As a supplement to the initial allocation and redistribution, philanthropy belongs to the third allocation, and the development of philanthropy can serve as an important means to adjust the economic inequality. We can properly adjust the economic inequality by actively developing philanthropy in China.

First is that we need to encourage the whole people to participate in it. Philanthropy is the career of the whole society and it must not be done by government alone or by certain enterprises, organizations or individuals. In the context 
of the increasing expansion of economic inequality, it is more necessary to form the prevailing custom to attract more groups to participate in charity.

Second, we need to strengthen the public trust construction of charitable organizations. Credibility has key function for displaying of charity organizations, so, we can say credibility is the vitality of charity, and there are some events that affect its public trust in the process of charitable organization. For this purpose, we need to strengthen the credibility construction of charity organizations from the aspects of building a healthy structure of charitable organization and using the information of donations.

Third, we need to strengthen government support for charities. Government support is an indispensable foundation and condition for the development of charity, which can be divided into two aspects: system support and tax preference. For this purpose, administrative procedures should be simplified, administrative efficiency of relevant institutions should be improved, and relevant tax incentives should be implemented to encourage more funds to enter the field of philanthropy.

\subsection{Energetically Promote the Establishment of Tax Collection and Administration System in China}

The perfection of tax collection and management system is the basis of the inheritance tax. When China does not have condition to levy the inheritance tax, we must vigorously promote our country's construction of tax collection and management system, preparing for levying inheritance tax, and provide the basis for the reform of other tax categories.

Firstly, we need to establish and complete the assessment system for resident property and introduce more market participants. At present, there is lack of corresponding evaluation system for resident property and the corresponding market subject in China. Thus, we need to establish and improve the assessment system of resident property, bring in market participants, and make evaluation market of resident property in our country, so as to lay a solid foundation for levying inheritance tax in China.

Secondly, it is necessary to establish a unified registration and management system for resident property to realize the dynamic management for resident property. On the one hand, it can provide accurate information of resident property for levying inheritance tax; on the other hand, it can prevent the loss of tax revenue and reduce the scale of capital outflows. Therefore, the unified registration and management system of resident property is very important for levying inheritance tax, which is another important basis for inheritance tax. On Jan. $1^{\text {st }}, 2016$, Ministry of Land and Resources announced Implementation Rules of the Provisional Regulations on Real Estate Registration, and China's real estate registration began to implement gradually, which was a good start. The registration of real estate is only a part of the unified registration of resident property. How to realize the interconnection of resident property information in the tax department is essential for establishing a unified management system. 
The construction of tax collection and administration system is a systematic project. We should take the construction of the tax collection and management system as an opportunity to strengthen our country's tax collection and administration ability; when we lay the groundwork for levying inheritance tax, we should also promote the reform of the existing tax system in China.

\section{Conclusions}

The text takes the theory of substitution effect of taxation and the theory of international capital flow as the theoretical basis to analyze the expected effect of levying inheritance tax in China for capital outflows, and discuss whether China has the condition to levy the inheritance tax based on this. In this way, the main conclusions we get are as follows:

1) The levy of inheritance tax will accelerate the expected effect for the capital outflows. In terms of the long-term co-integration equation, if the inheritance tax is levied under the unchanged condition, the scale of capital outflows will increase by $531,861,000$ dollars.

2) China is not suitable for levying inheritance tax at current stage. Combined with specific economic and social situation in our country, our country does not have the condition to levy the inheritance tax at current stage, otherwise, the scale of capital outflows in our country will be expended, which is not conducive to the stability of China's international balance of payments and the development of economy and society.

3) We need to take measures to adjust the gap between the rich and the poor in our country under current condition. Dialectical relationship between fairness and efficiency requests us to deal with the relationship between fairness and efficiency correctly. The efficiency is the material basis of fairness, and the fairness is the guarantee of efficiency, so, if the efficiency wants to rise again after reaching a certain level, the social fairness must be the guarantee; if we only pay attention to efficiency blindly, the unstable factors will be brought to the society.

\section{References}

[1] Xie, Y. (2014) China's Livelihood Development Report 2014. Peking University Press, Beijing.

[2] Li, J.X. (2015) China's Livelihood Development Report 2015. Peking University Press, Beijing.

[3] Li, S. and Wan, H.Y. (2015) Retrospect and Prospect for the Research on the Gap of Chinese Resident Property. Labor Market Research, No. 5, 28-44.

[4] Han, L. (2002) The Necessity of Levying Inheritance Tax under the Condition of Economic Globalization. Taxation Research, No. 8, 76-79.

[5] Liu, Z. (2003) Some Different Opinions about the Problems for Levying Inheritance Tax in China. Economics of Finance and Trade, No. 10, 74-77.

[6] Liu, R. and Liu, Z.C. (2013) The Levy of Inheritance Tax-The Historical Choice of China's Economic and Social Development. Taxation Research, No. 3, 34-39.

[7] San, S.A. (2013) Meaning and Institutional Arrangement of Levying Inheritance 
Tax in China. Taxation Research, No. 3, 43-46.

[8] Jia, K. (2014) Value Orientation of Inheritance Tax and Its Direction of Reform Design. Taxation Research, No. 4, 28-31.

[9] Gao, F.Q., Wang, C.C. and Wang, Z.W. (2015) The Experience of Inheritance Tax in Major Market Economy Country and Its Enlightenment. Public Finance Research, No. 8, 98-102.

[10] Peng, F. and Kang, L.L. (2003) China Should Levy Inheritance Tax Prudently. International Taxation in China, No. 5, 17-20.

[11] Xie, B. and Liu, F. (2014) Discussing the Unsuitability of Levying Inheritance Tax in Recent China. Price Theory and Practice, No. 2, 38-41.

[12] Li, H. and Wang, Y. (2015) Whether China Begins to Levy Inheritance Tax: The Thinking Based on Existence or Abolishment of Inheritance Tax. Public Finance Research, No. 11, 86-95.

[13] Liu, R. and Liu, Z. (2013) The Levy of Inheritance Tax-The Historical Choice of China's Economic and Social Development. Taxation Research, No. 3, 34-39.

[14] Huang, C. (2013) System Design under the Dilemma of Levying Inheritance Tax. Taxation Research, No. 3, 49-50.

[15] Gao, F. and Xu, K. (2013) Effect Analysis of Inheritance Tax System and Starting to Levy Inheritance Tax in China. Taxation Research, No. 3, 40-42.

[16] Xie, B. and Yang, N. (2013) Comparison of the Effects of Inheritance Tax and the Enlightenment to China. Price Theory and Practice, No. 12, 14-17. 